\title{
Antibacterial activity of ethanolic leaf extract of Aquilaria malaccensis against multidrug-resistant Gram-negative pathogen
}

\author{
${ }^{1}$ Jihadi, N.I.M., ${ }^{1}$ Hashim, Y.Z.H-Y., ${ }^{2}$ Rahim, N.A., ${ }^{1}$ Kamal, K.M., ${ }^{1}$ Noor, N.M., ${ }^{1}$ Sani, \\ M.S.A. and ${ }^{1, *}$ Maifiah, M.H.M. \\ ${ }^{1}$ International Institute for Halal Research and Training (INHART), Level 3, KICT Building, International \\ Islamic University Malaysia (IIUM), 53100, Jalan Gombak, Selangor, Malaysia \\ ${ }^{2}$ Faculty of Pharmacy, University of Malaya, 50603 Kuala Lumpur, Malaysia
}

Article history:

Received: 3 May 2020

Received in revised form: 5 June 2020

Accepted: 8 June 2020

Available Online: 7 August 2020

\section{Keywords:}

Aquilaria malaccensis,

Leaf extract,

Gram-negative pathogen,

Escherichia coli

Acinetobacter baumannii,

Klebsiella pneumoniae

DOI:

https://doi.org/10.26656/fr.2017.4(6).205

\begin{abstract}
The rapid emergence of resistant Gram-negative bacteria and the limited discovery of novel antibiotic is a global healthcare challenge. Many medicinal plants with potent bioactivities have been developed for the treatment of bacterial infections. Aquilaria malaccensis exhibits wide applications from perfumes and aromatic foods ingredients and great potential in medicines. In this study, crude leaf extract of A. malaccensis was evaluated for its antibacterial activity against several pathogenic Gram-negative bacteria. The leaves were processed and extracted by Soxhlet method using ethanol as the solvent. The antibacterial activity of the crude extract was tested by disc diffusion method, minimum inhibitory concentration (MIC) and minimum bactericidal concentration (MBC) against Acinetobacter baumannii (ATCC 19606), Klebsiella pneumoniae (ATCC 10031 and ATCC 700603) and Escherichia coli (ATCC 1129). Using the optimized method, the Soxhlet extract produced a yield of $178.41 \mathrm{mg} / \mathrm{g}$. Treatment of the extract at $200 \mathrm{mg} / \mathrm{mL}$ displayed the largest inhibition zones of $14.0 \mathrm{~mm}$ and $9.7 \mathrm{~mm}$ against $A$. baumannii and K. pneumoniae ATCC 10031, respectively. In contrast, against E. coli and K. pneumoniae ATCC 700603, smaller zones of inhibitions of $3.3 \mathrm{~mm}$ were demonstrated. The MIC values of the extract were $32 \mathrm{mg} / \mathrm{mL}$ against $A$. baumannii and $K$. pneumoniae ATCC 10031 and $64 \mathrm{mg} / \mathrm{mL}$ against $E$. coli and $K$. pneumoniae ATCC 700603. The MBC values of the extract were consistent with the MIC values for all the bacteria investigated. Overall, this study was the first to show antibacterial activity of $A$. malaccensis leaves extract particularly against $A$. baumannii and $K$. pneumoniae and potentially develop for the treatment of resistant bacteria.
\end{abstract}

\section{Introduction}

Tropical rainforest is a treasure house of many medicinal plant species. Historically, these medicinal plants or herbs have been used as folklore medicine for treating various infectious diseases and ailments. Herbal medicines constitute the Traditional and Complementary Medicine ( $\mathrm{T}$ and $\mathrm{CM}$ ) Products where the users are mainly from Europe, Africa, Asia, Australia and North America (WHO, 2013). Therapeutic effects from the medicinal plants are conferred by their constituent of bioactive compounds originated from the plant's secondary metabolism generally grouped as carotenoids, phenolics, alkaloids, nitrogen-containing compounds and organosulfur compounds (Cowan, 1999). Over the past few decades, much more attention has been placed on medicinal plants which have become a new promising source of antibacterial agents (Arifullah et al., 2014).

The rising incidence of bacterial infections due to multidrug-resistant (MDR) pathogens is a critical health issue globally. Worryingly, a particular concern is associated with the emergence of MDR Gram-negative bacteria that are resilient to almost all antibiotics (CDC, 2013). In addition, the dry discovery and development pipeline of new antibiotics further lead to catastrophic consequences due to the lack of effective treatment schemes observed in patients (Schäberle and Hack, 2014). The threat is projected to persist and further rise by 2050 which would potentially lead to a mortality rate of 10 million people every year (O’Neill, 2014). Studies have reported on the increase in the prevalence of resistant bacteria, particularly of Gram-negative group including, Escherichia coli and Klebsiella pneumoniae 
(Guh et al., 2015; Zhang et al., 2018) as well as Acinetobacter baumannii (Almasaudi, 2018) that contributed to high mortality rates of more than $30 \%$ (Gutiérrez-Gutiérrez et al., 2017). Multiple factors and mechanisms of antimicrobial resistance in Gramnegative bacteria constitute a great challenge which requires serious attention and proactive action to counter the problem.

A considerable number of local medicinal plants have been reported to exhibit antibacterial properties against both Gram-negative and Gram-positive bacteria. Uyub et al. (2010) evaluated the in-vitro antibacterial activity of more than thirty selected Malaysian ethnobotanical plants and found that all the extract possessed antibacterial activity against several common pathogenic bacteria including E. coli, Pseudomonas aeruginosa and Staphylococcus aureus. A recent study revealed that 21 plant extracts of commonly used traditional medicine in Indonesia showed an inhibition effect on Enterococcus faecalis, $P$. aeruginosa and $S$. aureus (Romulo et al., 2018). Medicinal plants are generally considered as safe, effective and possess minimal undesirable side effects (Rafieian-kopaei, 2012). Their actions are complex and tend to have several broad actions such as complementary or synergistic actions on physiological systems at the same time (Nasri and Shirzad, 2013). From this point, the development of new antibacterial agents incorporating plants as a means of therapy has gained significant interest as it produces a vast range of pharmacologically active compound (Jamshidi-Kia et al., 2018).

Aquilaria malaccensis (Thymelaeaceae Family) is a precious plant species which produces a valuable nontimber fragrant wood "resin" (Swee, 2008). The plant widely spread across the forest of Malaysia and Indonesia (known as gaharu and karas) as well as other regions including Bangladesh, India Myanmar, Philippines, Singapore and Thailand (Begum, 2016). The uses of agarwood are not restricted to incense and perfumery. The leaves can be processed into dietary supplements and consumed in food and beverage industry such as herbal tea, biscuits and instant noodle (Chen, 2013). Currently, the applications of agarwood have been increasingly explored for pharmaceuticals purpose obtained from other parts of the tree (Wang et al., 2018). Despite its abundance of supply, research on the leaf from the non-inoculated plant, the one without the introduction of pathogen or antigen to induce its resin are still infrequent (Zainurin, Hashim, Mohamed Azmin et al., 2020). Studies indicated that leaves from the tree contained great potential of bioactivities such as antioxidant (Begum, 2016), anti-inflammatory (Eissa et al., 2018), anti-hyperglycemic (Pranakhon et al., 2011) as well as antibacterial (Hendra et al., 2016). In a phytochemical screening study by Khalil et al. (2013), alkaloids, saponins, flavonoids, tannins and terpenoids were found in both non-inoculated and inoculated sample of $A$. malaccensis leaves and this could be exploited for the development of therapeutic agents. The present study was performed to demonstrate the in vitro antibacterial activity of crude A. malaccensis leaves extracts against Gram-negative bacteria including E. coli, $K$. pneumoniae and A. baumannii.

\section{Materials and methods}

\subsection{Plant material and bacterial strains}

A. malaccensis leaves were obtained from the private agarwood plantation, Global Root Resources located in Kajang, Selangor, Malaysia freshly collected in January 2020. Gram-negative bacteria of laboratory (reference) strains from American Type Culture Collection (ATCC) of E. coli ATCC 1129, A. baumannii ATCC 19606, K. pneumoniae ATCC 10031 and ATCC 700603 were investigated. A stock solution of the crude extract was prepared by dissolving the extract with Dimethylsulfoxide (DMSO) (Chemiz, 100\%, Malaysia) to produce an initial concentration of $300 \mathrm{mg} / \mathrm{mL}$. The stock solution was then further diluted to certain specific concentrations for further use.

\subsection{Ethanolic leaves extraction}

The fresh leaves of $A$. malaccensis ( $1 \mathrm{~kg}$ ) were watery washed, rinsed with distilled water and dried in the oven at $50^{\circ} \mathrm{C}$ for $24 \mathrm{hrs}$. The dried leaves were grounded into a fine powder and kept at room temperature in a closed container. The extraction of leaves powder was in reference to the previous method with modification (Zainurin, Samsudin, Hashim et al., 2020). Leaves powder of $20 \mathrm{~g}$ were extracted with 300 $\mathrm{mL}$ ethanol (HmbG, 99\%, Germany) at its boiling point $78^{\circ} \mathrm{C}$ in Soxhlet extractor for $18 \mathrm{hrs}$ until the colour of solvent in the thimble becomes colourless. The extraction was performed in dark, at 1:15 of leaves-tosolvent ratio and in triplicates. The filtrate of ethanol solvent was evaporated by the rotary evaporator (Heidolph, Instruments $\mathrm{GmbH}$ and $\mathrm{CO}$, Schwabach, Germany) at $45^{\circ} \mathrm{C}$ under 100 mbar and kept at $4^{\circ} \mathrm{C}$ until further use. The yield of crude extract was calculated as the percentage yield.

\subsection{Preparation of bacteria}

Bacterial isolates of $E$. coli ATCC 1129, A. baumannii ATCC 19606, K. pneumoniae ATCC 10031 and ATCC 700603 from the $-20^{\circ} \mathrm{C}$ frozen stocks were sub-cultured onto a nutrient agar plate and incubated for $16 \mathrm{hrs}$ to $18 \mathrm{hrs}$ at $37^{\circ} \mathrm{C}$. A single colony of the 
respective Gram-negative bacteria were inoculated into $10 \mathrm{~mL}$ Mueller Hinton Broth media and grown for $16 \mathrm{hrs}$ to $18 \mathrm{hrs}$ at $37^{\circ} \mathrm{C}$. The overnight cultures of the bacterial isolates were diluted using sterile normal saline to give an inoculums size of about $10^{6} \mathrm{CFU} / \mathrm{mL}$ with reference to the McFarland turbidity standard.

\subsection{Antimicrobial susceptibility test}

The crude $A$. malaccensis extract was tested for its antibacterial activity against the $E$. coli ATCC $1129, A$. baumannii ATCC 19606, K. pneumoniae ATCC 10031 and ATCC 700603 using disc diffusion method according to the European Committee on Antimicrobial Susceptibility Testing (EUCAST) (Matuschek et al., 2014). Bacterial culture of $0.5 \mathrm{~mL}$ of $10^{6} \mathrm{CFU} / \mathrm{mL}$ was aseptically dispensed and streaked on the surface of the solid nutrient agar plate. A sterile, blank disc of $6 \mathrm{~mm}$ in diameter was mounted on the agar plate. The extract $(5$ $\mu \mathrm{L}$ ) of different concentrations at $100 \mathrm{mg} / \mathrm{mL}$ and 200 $\mathrm{mg} / \mathrm{mL}$ were impregnated onto the discs and allowed to dry. To measure the effect of plant extract, Tetracycline $(5 \mathrm{mg} / \mathrm{mL})$ and DMSO (Chemiz, 100\%, Malaysia) were used as the positive and negative controls, respectively. The plates were prepared in triplicates and incubated at $37^{\circ} \mathrm{C}$ for $16 \mathrm{hrs}$ to $18 \mathrm{hrs}$. Antibacterial activity of the extract was evaluated by measuring the diameter of the inhibition zone around the discs (Matuschek et al., 2014).

\subsection{Minimum inhibitory concentrations of crude extracts}

The minimum inhibitory concentration (MIC) of $A$. malaccensis crude extract was determined using broth microdilution method (Wiegand et al., 2008). A volume of $100 \mu \mathrm{L}$ of different concentrations of crude extract (2fold serial dilution) was loaded into the sterile 96-well plates. The initial bacterial inoculum of $100 \mu \mathrm{L}$ of $\sim 10^{6}$ $\mathrm{CFU} / \mathrm{mL}$ was then added into each well. The wells without antibiotic and crude extract served as growth controls. The assay plate was incubated at $37^{\circ} \mathrm{C}$ for 16 hrs to $18 \mathrm{hrs}$. The MIC was taken from the well with the lowest concentration that shows a clear solution.

\subsection{Minimum bactericidal concentrations of crude extracts}

The minimum bactericidal concentration (MBC) of the crude leave extract was determined by plating 100 $\mu \mathrm{L}$ of the bacterial culture from each well of the broth microdilution from the MIC assay onto the nutrient agar plate (Balouiri et al., 2016). The plate was incubated at $37^{\circ} \mathrm{C}$ for $16 \mathrm{hrs}$ to $18 \mathrm{hrs}$. The MBC is defined as the lowest concentration of the extract that resulted in no growth of a single bacterial colony on a nutrient agar plate.

\section{Results}

\subsection{Yield of crude leaf extract}

The final product produced was in a dark green and waxy thick with a final yield of $178.41 \mathrm{mg} / \mathrm{g}$, which was approximately $17.84 \%$ yield.

\subsection{Antimicrobial susceptibility test}

The antibacterial activity of the crude ethanolic extracts of $A$. malaccensis leaves was evaluated using disc diffusion method. The crude extract exhibited antibacterial activities against the Gram-negative bacteria of E. coli ATCC 1129, A. baumannii ATCC 19606 and K. pneumoniae ATCC 10031 and 700603 as indicated by the varying degree of zones of inhibitions (Table 1). Compared to other bacteria tested, for $A$. baumannii ATCC 19606, the largest inhibition zone diameters of $14.0 \mathrm{~mm}$ and $9.0 \mathrm{~mm}$ treated at $200 \mathrm{mg} / \mathrm{mL}$ and $100 \mathrm{mg} / \mathrm{mL}$ extracts, respectively, were demonstrated. In addition, the crude leave extract showed good antibacterial activities against $K$. pneumoniae ATCC 10031 with $9.7 \mathrm{~mm}$ and $6.7 \mathrm{~mm}$ zones of inhibitions tested at $200 \mathrm{mg} / \mathrm{mL}$ and $100 \mathrm{mg} /$ $\mathrm{mL}$, respectively. As for E. coli ATCC 1129 and $K$. pneumoniae ATCC 700603, the diameters of zones of inhibitions were relatively small which were $4.0 \mathrm{~mm}$ to $3.0 \mathrm{~mm}$ at $200 \mathrm{mg} / \mathrm{mL}$ and $100 \mathrm{mg} / \mathrm{mL}$, respectively. The standard antibiotic tetracycline $(5 \mathrm{mg} / \mathrm{mL})$ which served as the positive control significantly exhibited the highest zone of inhibitions in all the Gram-negative bacteria tested ranging from $6.7 \mathrm{~mm}$ to $21.0 \mathrm{~mm}$. On the other hand, negative control showed no inhibition zones in all

Table 1. Antibacterial activity of ethanolic extract of $A$. malaccensis by disc diffusion method

\begin{tabular}{ccccc}
\hline \multirow{2}{*}{ Extract/Antibiotic } & \multicolumn{4}{c}{ Inhibition Zone Diameter $(\mathrm{mm} \pm \mathrm{SD})^{1}$} \\
\cline { 2 - 5 } & $\begin{array}{c}\text { E. coli } \\
\text { ATCC 1129 }\end{array}$ & $\begin{array}{c}\text { K. pneumoniae } \\
\text { ATCC 700603 }\end{array}$ & $\begin{array}{c}\text { K. pneumoniae } \\
\text { ATCC 10031 }\end{array}$ & $\begin{array}{c}\text { A. baumannii } \\
\text { ATCC 19606 }\end{array}$ \\
\hline $100 \mathrm{mg} / \mathrm{mL}$ & $3.0 \pm 0$ & $3.0 \pm 0$ & $6.7 \pm 1.1$ & $9.0 \pm 1.0$ \\
$200 \mathrm{mg} / \mathrm{mL}$ & $3.3 \pm 0.6$ & $3.3 \pm 0.6$ & $9.7 \pm 0.6$ & $14.0 \pm 0$ \\
${ }^{2}$ Tetracycline & $20.7 \pm 0.6$ & $6.7 \pm 1.1$ & $21.0 \pm 1.0$ & $21.0 \pm 1.0$ \\
\hline
\end{tabular}

Values are means of three replicates $(\mathrm{N}=3 \pm \mathrm{SD})$.

${ }^{1}$ Inhibition zone excluding diameter disk $(6 \mathrm{~mm})$

${ }^{2}$ Tetracycline at $5 \mathrm{mg} / \mathrm{mL}$ 
the bacteria evaluated in this study.

\subsection{Minimum inhibitory concentrations and minimum bactericidal concentrations}

Based on the visual investigation of the bacterial culture, the MIC value of the crude leave extract of $A$. malaccensis against the A. baumannii ATCC 19606 and K. pneumoniae ATCC 10031 was at $32 \mathrm{mg} / \mathrm{mL}$ (Table 2). In turn, the crude extract of $A$. malaccensis exhibited a higher MIC value of $64 \mathrm{mg} / \mathrm{mL}$ against the $E$. coli ATCC 1129 and K. pneumoniae ATCC 700603 (Table 2). Furthermore, the results indicated that the $\mathrm{MBC}$ values of the crude extract were similar to the MIC for all the bacteria tested (Table 2).

Table 2. MIC and MBC values of the ethanolic crude extract of A. malaccensis leaves against different Gram-negative bacteria isolates.

\begin{tabular}{lcc}
\hline \multicolumn{1}{c}{ Isolates } & MIC $(\mathrm{mg} / \mathrm{mL})$ & $\mathrm{MBC}(\mathrm{mg} / \mathrm{mL})$ \\
\hline A. baumannii ATCC 19606 & 32 & 32 \\
K. pneumoniae ATCC 10031 & 32 & 32 \\
K. pneumoniae ATCC 700603 & 64 & 64 \\
E. coli ATCC 1129 & 64 & 64 \\
\hline
\end{tabular}

\section{Discussion}

Soxhlet extraction of the A. malaccensis leaves using ethanol as the solvent was performed according to the previously optimized method with slight modifications (Zainurin, Samsudin, Hashim et al., 2020). The yield produced approximately $17.84 \%$ which was consistent with the previous report that employed a similar method for A. malaccensis leaves with $18.45 \%$ yield (Zainurin, Samsudin, Hashim et al., 2020). Various studies have shown that the types of solvents used for the extraction of plant materials significantly affect the amount and the effectiveness of the extracts obtained (Koffi et al., 2010; Anokwuru et al., 2011). Compared to other extraction solvents, polar solvents such as ethanol and methanol provide a better capability in extracting secondary metabolites such as flavonoids, phenolic acids and alkaloids (Šibul et al., 2016). Ethanol has been known as an effective and safe polar organic solvent with its wide solubility properties that can extract low molecular weight molecule and moderately polar substances (FDA, 2012). It has been reported in a previous study that ethanolic extracts of A. malaccensis leaf gave higher yield $(121.34 \pm 31.6 \mathrm{mg} / \mathrm{g})$ as compared to hexane extract $(34.38 \pm 1.0 \mathrm{mg} / \mathrm{g})$ (Hashim et al., 2019).

Crude ethanolic leaves extract of $A$. malaccensis demonstrated a varying degree of antibacterial activity against Gram-negative bacteria including E. coli, $A$. baumannii, and $K$. pneumoniae. The results demonstrated the presence of clear zones of inhibition around the disc mounted on the nutrient agar plate at the

concentrations of $100 \mathrm{mg} / \mathrm{mL}$ and $200 \mathrm{mg} / \mathrm{mL}$ of the $A$. malaccensis leaves crude extract (Figure 1). The $A$. malaccensis extract showed a strong antibacterial activity against $A$. baumannii ATCC $19606(9.0 \mathrm{~mm}-$ $14.0 \mathrm{~mm}$ ) and $K$. pneumoniae ATCC $10031(6.7 \mathrm{~mm}-$ $9.7 \mathrm{~mm}$ ) (Figure 1). Compared to other Gram-negative bacterial strains, the crude extract showed moderate antibacterial activity on E. coli ATCC 1129 and $K$. pneumoniae ATCC 700603 ( $3.0 \mathrm{~mm})$. Previous studies have been reported on the chloroform extract of agarwood which showed good antibacterial activity against E. coli, $P$. aeruginosa, and $S$. aureus with inhibition zones between $16-17 \mathrm{~mm}$ at $50 \mathrm{mg} / \mathrm{mL}$ of concentration (Begum, 2016; Hendra et al., 2016). A recent study by Singh et al. (2019) reported on the sensitivity of A. baumannii, K. pneumoniae and E. coli on commercialized agarwood oil which varied from $30 \%$ to $70 \%$. To the best of our knowledge, our present work is the first to report on the antibacterial activity of ethanolic crude leave extract of $A$. malaccensis against $A$. baumannii and K. pneumoniae.

A

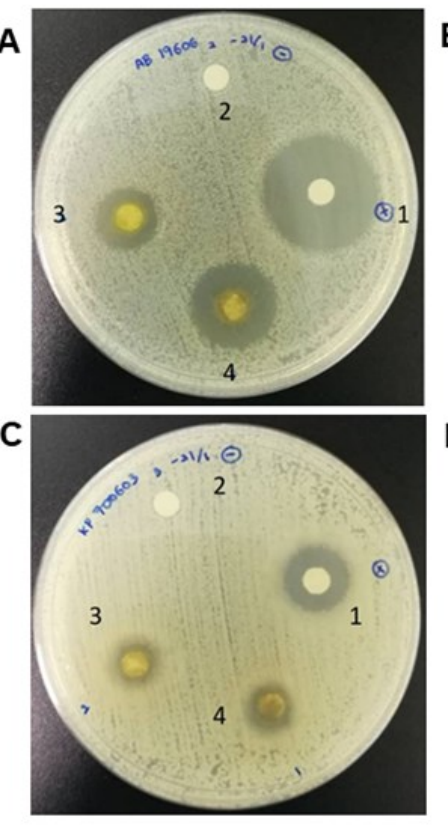

Figure 1. Visible zone of inhibitions produced by $A$. malaccensis extracts against Gram-negative bacteria (A) $A$. baumannii ATCC 19606, (B) K. pneumoniae ATCC 10031, (C) K. pneumonia ATCC 700603 and (D) E. coli ATCC 1129. $1=$ tetracycline as positive control $(5 \mathrm{mg} / \mathrm{mL}) ; 2=$ DMSO as negative control; $3=100 \mathrm{mg} / \mathrm{mL} ; 4=200 \mathrm{mg} / \mathrm{mL}$.

The presence of antibacterial activity observed from the crude extract of $A$. malaccensis leaves on $A$. baumannii and $K$. pneumonia was most likely contributed by the constituents of active biological compounds. Qualitative screening of phytochemical compounds of methanolic A. malaccensis leave extract revealed the presence of alkaloids, and phenolic compounds (flavonoids, terpenoids, and tannins) that likely to contribute to its antibacterial properties (Khalil et al., 2013). The results were supported by Hendra et al. 
(2016) where reported on the antibacterial activity of chloroform fraction of $A$. malaccensis leave extract on $S$. aureus and E. coli tested at concentration $300 \mathrm{mg} / \mathrm{mL}$ potentially due to the presence of alkaloid and terpenoid (Hendra et al., 2016). Analysis by gas chromatographymass spectroscopy (GC-MS) revealed that the methanolic and ethanolic extract of agarwood leaves contain hexadecenoic acid which is potentially a major compound contributing to its strong antibacterial activity against Gram-negative bacteria (Khalil et al., 2013; Zainurin, Hashim, Mohamed Azmin et al., 2020). Hexadecanoic acid is one of the most common saturated fatty acids found in animals and plants and has been reported widely to possess antibacterial property (Aparna et al., 2012).

The results of disk diffusion test on A. baumannii ATCC 19606 and K. pneumonia ATCC 10031 showed notable antibacterial activity with a concentrationdependent effect as indicated by the increased diameter of the zone of inhibition as the concentration increased from $100 \mathrm{mg} / \mathrm{mL}$ to $200 \mathrm{mg} / \mathrm{mL}$ (Figure 1 and Table 2). Similarly, the results are consistent with a previous study by Hendra et al. (2016) that showed the increasing diameter of the inhibition zone by the increasing concentrations of extract in E. coli and $S$. aureus. In addition, Alimon et al. (2011) found that the increased in inhibition zones of Aquilaria crassna methanolic leaf extract occurred as the concentration of the extracts increased from $4 \mathrm{mg} / \mathrm{mL}$ to $10 \mathrm{mg} / \mathrm{mL}$ when tested against Bacillus spizzienii, S. aureus, Shigella flexneri and $P$. aeruginosa. Nevertheless, antibacterial activity for the K. pneumonia ATCC 700603 and E. coli ATCC 1129 showed no significant effects when treated at different extract concentrations of $100 \mathrm{mg} / \mathrm{mL}$ and 200 $\mathrm{mg} / \mathrm{mL}$.

In the present study, the results showed that the MIC values of $A$. malaccensis crude leave extracts were 32 $\mathrm{mg} / \mathrm{mL}$ against $A$. baumannii ATCC 19606 and $K$. pneumonia ATCC 10031 which were lower than the MIC values for E. coli ATCC 1129 and K. pneumoniae ATCC $700603(64 \mathrm{mg} / \mathrm{mL})$. The results highlight the susceptibility of the different Gram-negative bacteria strains that showed A. baumannii ATCC 19606 and $K$. pneumonia ATCC 10031 were more susceptible towards the crude extract of $A$. malaccensis leaves as compared to the E. coli ATCC 1129 and K. pneumoniae ATCC 700603. The results highlight on the antibacterial activity of crude extract and we expect a stronger activity from a purified fraction of $A$. malaccensis leaves likely due to the presence of hexadeconoic acid, alkaloid and terpernoid. Notably, the same MBC value and the MIC values were obtained against all the bacteria tested. This demonstrates that the concentrations of extract needed to inhibit the growth of organisms were sufficient to kill the organisms and this may give an extract a positive vibe as a bactericidal agent against Gram-negative bacteria.

\section{Conclusion}

The ethanolic extract of $A$. malaccensis leaves showed good antibacterial activity against different strains of Gram-negative pathogens as tested at two different concentrations. The strongest antibacterial activity was observed against $A$. baumannii ATCC 19606 and K. pneumoniae ATCC 10031 with MIC and MBC value of $32 \mathrm{mg} / \mathrm{mL}$, to a lesser extent against $E$. coli ATCC 1129 and K. pneumoniae ATCC 700603. Overall, the results highlight the potential of $A$. malaccensis leaves as a novel source of antibacterial agents in the fight against the problem of antimicrobial resistance in the Gram-negative bacterial infections.

\section{Conflict of interest}

The authors declare no conflict of interest.

\section{Acknowledgement}

This work was supported by the IIUM Research Acculturation Grant Scheme (IRAGS) (IRAGS180100011.) received from the International Islamic University Malaysia (IIUM).

\section{References}

Alimon, H., Ariffin, N. M., Azziz, S.A., Ibrahim, R., Jaafar, M.F. and Sukari, M.A. (2011). Biological activities of leaf and bark from Aquilaria crassna Pierre (Gaharu) presented at UMTAS 2011: empowering science, technology and innovation towards a better tomorrow, Kuala Terengganu, Malaysia, 11-13 July 2011. Malaysia: Kuala Terengganu.

Almasaudi, S.B. (2018). Acinetobacter spp. As nosocomial pathogens: Epidemiology and resistance features. Saudi Journal of Biological Science, 25(3), 586-596. https://doi.org/10.1016/j.sjbs.2016.02.009

Anokwuru, C.P., Anyasor, G.N., Ajibaye, O., Fakoya, O. and Okebugwu, P. (2011). Effect of extraction solvents on phenolic, flavonoid and antioxidant activities of three Nigerian medicinal plants. Nature and Science, 9(7), 53-61.

Aparna, V., Dileep, K.V., Mandal, P.K., Karthe, P., Sadasivan, C. and Haridas, M. (2012). Antiinflammatory property of n-hexadecanoic acid: structural evidence and kinetic assessment. Chemical Biology and Drug Design, 80(3), 434-439. https:// doi.org/10.1111/j.1747-0285.2012.01418.x 
Arifullah, M., Vikram, P., Chiruvella, K.K., Shaik, M.M. and Ripain, I.H.A. (2014). A review on Malaysian plants used for screening of antimicrobial activity. Annual Research and Review in Biology, 4(13), 2088 -2132. https://doi.org/10.9734/ARRB/2014/8258

Balouiri, M., Sadiki, M. and Ibnsouda, S.K. (2016). Methods for in vitro evaluating antimicrobial activity: A review. Journal of Pharmaceutical Analysis, 6(2), 71-79. https://doi.org/10.1016/ j.jpha.2015.11.005

Begum, Y. (2016). Study on agarwood (Aquilaria malaccensis) to evaluate antibacterial and Antioxidant activities of n-hexane, chloroform and ethyl acetate extracts. Pharmatutor, 4(2), 2-5.

Centers for Disease Control and Prevention (CDC). Antibiotic resistance threats in the United States, 2013. (2013). Retrieved on May 3, 2020 from CDC website: https://www.cdc.gov/drugresistance/pdf/arthreats-2013-508.pdf

Cowan, M. (1999). Plant products as antimicrobial agents,. Clinical Microbiology Reviews, 12(4), 534 564. https://doi.org/10.1128/CMR.12.4.564

Eissa, M., Hashim, Y.Z.H-Y. and Zainurin, N.A.A. (2018). Aquilaria malaccensis leaf as an alternative source of anti-inflammatory compounds. International Journal on Advanced Science, Engineering and Information Technology, 8(4-2), 1625-1632. https://doi.org/10.18517/ijaseit.8.42.7054

FDA (2012). Guidance for industry. Retrieved May 3, 2020 from FDA website: https://www.fda.gov/ media/133650/download (Accessed: 3rd May 2020).

Guh, A.Y., Bulens, S.N., Mu, Y., Jacob, J.T., Reno, J., Scott, J., Wilson, L.E., Vaeth, E., Lynfield, R., Shaw, K.M., Vagnone, P.M.S., Bamberg, W.M., Janelle, S.J., Dumyati, G., Concannon, C., Beldavs, Z., Cunningham, M., Cassidy, P.M., Phipps, E.C., Kenslow, N., Travis, Tatiana., Lonsway, D., Rasheed, J.K., Limbago, B.M. and Kallen, A.J. (2015). Epidemiology of carbapenem-resistant Enterobacteriaceae in 7 US communities, 20122013. Journal of the American Medical Association, 314(14), 1479-1487. https://doi.org/10.1001/ jama.2015.12480

Gutiérrez-Gutiérrez, B., Salamanca, E., de Cueto, M., Hsueh, P.R., Viale, P., Paño-Pardo, J.R., Venditti, M., Tumbarello, M., Daikos, G., Cantón, R., Doi, Y., Tuon, F.F., Karaiskos, I., Pérez-Nadales, E., Schwaber, M.J., Azap, Ö.K., Souli, M., Roilides, E., Pournaras, S., Akova, M., Perez, F., Bermejo, J., Oliver, A., Almela, M., Lowman, W., Almirante, B., Bonomo, R.A., Carmeli, Y., Paterson, D.L., Pascual, A., Rodriguez-Bano, J. and REIPI/ESGBIS/
INCREAMENT Investigators. (2017). Effect of appropriate combination therapy on mortality of patients with bloodstream infections due to carbapenemase-producing Enterobacteriaceae (INCREMENT): a retrospective cohort study. The Lancet Infectious Diseases, 17(7), 726-734. https:// doi.org/10.1016/S1473-3099(17)30228-1

Hashim, Y.Z.H-Y, Jamil M.A.M., Jamal, P., Zainurin, N.A.A. and Azziz S.S.S.A. (2019). Hydrodistillation and Soxhlet extraction of Agarwood leaf extract from Aquilaria malaccensis. Malaysian Journal of Fundamental and Applied Sciences, 15(6), 842-846.

Hendra, H., Moeljopawiro, S. and Nuringtyas, T.R. (2016). Antioxidant and antibacterial activities of agarwood (Aquilaria malaccensis Lamk.) leaves. AIP Conference Proceedings, 1755(1), 140004; https://doi.org/10.1063/1.4958565.

Jamshidi-Kia, F., Lorigooini, Z. and Amini-Khoei, H. (2018). Medicinal plants: Past history and future perspective. Journal of HerbMed Pharmacology, 7 (1), 1-7. https://doi.org/10.15171/jhp.2018.01

Khalil, A.S., Rahim, A.A., Taha, K.K. and Abdallah, K.B. (2013). Characterization of methanolic extracts of agarwood leaves (Aquilaria malaccensis). Journal of Applied and Industrial Sciences, 1(3), 78-88.

Koffi, E., Sea, T., Dodehe, Y. and Soro, S. (2010). Effect of solvent type on extraction of polyphenols from twenty-three Ivorian plants. Journal of Animal and Plant Sciences, 5(3), 550-558.

Matuschek, E., Brown, D.F.J. and Kahlmeter, G. (2014). Development of the EUCAST disk diffusion antimicrobial susceptibility testing method and its implementation in routine microbiology laboratories. Clinical Microbiology and Infection, 20(4), 255-266. https://doi.org/10.1111/1469-0691.12373

Nasri, H. and Shirzad, H. (2013). Toxicity and safety of medicinal plants. Journal of HerbMed Pharmacology, 2(2), 21-22.

O’Neill, J. (2014). Antimicrobial resistance: tackling a crisis for the health and wealth of nations. Retrieved from website: https://amr-review.org/sites/default/ files/AMR $\% 20$ Review $\% 20$ Paper $\% 20-\%$ 20Tackling\%20a $\% 20$ crisis $\% 20$ for $\% 20$ the $\%$ 20health\%20and\%20wealth\%20of\%20nations_1.pdf

Pranakhon, R., Pannangpetch, P. and Aromdee, C. (2011). Antihyperglycemic activity of agarwood leaf extracts in STZ-induced diabetic rats and glucose uptake enhancement activity in rat adipocytes. Songklanakarin Journal of Science and Technology, 33(4), 405-410.

Rafieian-kopaei, M. (2012). Medicinal plants and human needs. Journal of HerbMed Pharmacology, 1(1), 1- 
2.

Romulo, A., Zuhud, E.A.M., Rondevaldova, J. and Kokoska, L. (2018). Screening of in vitro antimicrobial activity of plants used in traditional Indonesian medicine. Pharmaceutical Biology, 56 (1), 287-293. https:// doi.org/10.1080/13880209.2018.1462834

Schäberle, T.F. and Hack, I.M. (2014). Overcoming the current deadlock in antibiotic research. Trends in Microbiology, 22(4), 165-167. https:// doi.org/10.1016/j.tim.2013.12.007

Šibul, F.S., Orčić, D.Z., Svirčev, E. and Mimica-Dukić, N.M. (2016). Optimization of extraction conditions for secondary biomolecules from various plant species. Hemijska Industrija, 70(4), 473-483. https:// doi.org/10.2298/HEMIND150531053S

Singh, B.R., Sinha, D.K., Kumar, O.V., Vadhana, P., Bhardwaj, M., Saraf, A., Dubey, S., Pawde, A.M., De, U.K. and Gupta, V.K. (2019). Antimicrobial activity of agarwood oil against Multiple-DrugResistant (MDR) microbes of clinical, food and environmental origin. Current Drug Discovery Technologies, 17(3), 348-356. https:// doi.org/10.2174/1570163816666190125163536

Swee, L.L.C. (2008). Agarwood (Aquilaria malaccensis) in Malaysia. International Expert Workshop on CITES Non-Detriment Findings. Cancun, Mexico.

Uyub, A.M., Azlan, A.A., Fariza, S.S. and Nwachukwu, I.N. (2010). In-vitro antibacterial activity and cytotoxicity of selected medicinal plant extracts from Penang Island Malaysia on some pathogenic bacteria. Ethnobotany Research and Applications, 8, 95-106. https://doi.org/10.17348/era.8.0.95-106

Wang, S., Yu, Z., Wang, C., Wu, C., Guo, P. and Wei, J. (2018). Chemical constituents and pharmacological activity of agarwood and aquilaria plants. Molecules, 23(2), $342 . \quad \mathrm{https} / / /$ doi.org/10.3390/ molecules 23020342

WHO traditional medicine strategy: 2014-2023. (2013). Retrieved on May 3, 2020 from WHO website: https://www.who.int/medicines/publications/ traditional/trm_strategy14_23/en/

Wiegand, I., Hilpert, K. and Hancock, R.E.W. (2008). Agar and broth dilution methods to determine the minimal inhibitory concentration (MIC) of antimicrobial substances. Nature Protocols, 3(2), 163-175. https://doi.org/10.1038/nprot.2007.521

Zainurin, N.A.A., Hashim, Y.Z.H-Y., Mohamed Azmin, N.F. and Al-Khatib, M.F.R. (2020). Understanding the effects of different parameters of soxhlet extraction on bioactive compounds from Aquilaria malaccensis leaf through GCMS-based profiling.
Food Research, 4(Suppl.1), 63-73. https:// doi.org/10.26656/fr.2017.4(S1).S09

Zainurin, N.A.A., Samsudin, N., Hashim, Y.Z.H-Y., AlKhatib, M.F.R., Azmin, N.F.M. and Maifiah, M.H.M. (2020). Response surface optimization of the yield of agarwood (Aquilaria malaccensis) leaf extract using soxhlet extraction. International Journal of Recent Technology and Engineering, 8 (6), 1926-1934. https://doi.org/10.35940/ ijrte.F8013.038620

Zhang, Y., Wang, Q., Yin, Y., Chen, H., Jin, L., Gu, B., Xie, L., Yang, C., Ma, X., Li, H., Li, W., Zhang, X., Liao, K., Man, S., Wang, S., Wen, H., Li, B., Guo, Z., Tian, J., Pei, F., Liu, L., Zhang, L., Zou, C., Hu, T., Cai, J., Yang, H., Huang, J., Jia, X., Huang, W., Cao, B. and Wang, H. (2018). Epidemiology of carbapenem-resistant Enterobacteriaceae infections: Report from the China CRE Network. Antimicrobial Agents and Chemotherapy, 62, e01882-17. https:// doi.org/10.1128/AAC.01882-17 